\title{
EFEKTIVITAS PENGGUNAAN BOOKLET UNTUKMEREMEDIASI KESALAHAN SISWA PADA MATERI PEMUAIAN ZAT DI KELAS VII SMP NEGERI 1 TANGARAN KABUPATEN SAMBAS
}

\author{
Nurussaniah $^{1}$, Wahyudi ${ }^{2}$, Novi Sri Hidayati ${ }^{3}$ \\ Pendidikan Fisika, FPMIPA dan Teknologi, IKIP PGRI Pontianak \\ Email :nurussaniah@gmail.com
}

\begin{abstract}
Abstrak
Penelitian ini bertujuan untuk mengetahui efektivitas penggunaan booklet untuk meremediasi kesalahan siswa pada materi pemuaian zat di kelas VII SMP Negeri 1 Tangaran Kabupaten Sambas. Metode penelitian yang digunakan dalam penelitian ini adalah penelitian eksperimen dan bentuk penelitian Pre-Experimenal Designs dengan rancangan penelitian One Group Pretest Postest Design. Sebanyak 27 siswa kelas VIIB SMP Negeri 1 Tangaran Kabupaten Sambas yang dipilih secara intact group berpartisipasi dalam penelitian ini.Alat pengumpul data dalam penelitian ini yaitu tes tertulis berupa pilihan ganda menggunakan tiga alternatif jawaban dan disertai dengan alasan terbuka. Hasil penelitian menunjukkan bahwa penggunaan boklet efektif untuk meremediasi kesalahan siswa pada materi pemuaian zat dengan kategori tinggi untuk 20 siswa, sedang untuk 6 siswa dan rendah untuk 1 siswa. Selain itu penggunaan booklet juga efektif untuk meremediasi kesalahan pada materi pemuaian zat dengan kategori tinggi untuk 5 indikator, sedang untuk 4 indikator dan rendah untuk 1 indikator.
\end{abstract}

Kata kunci: efektifitas, remediasi, pemuaian zat, booklet, kesalahan siswa

\section{PENDAHULUAN}

Ilmu Pengetahuan Alam (IPA) merupakan konsep pembelajaran alam danmempunyai hubungan yang sangat luas terkait dengan kehidupan manusia. Pembelajaran IPA sangat berperan dalam proses pendidikan dan juga perkembangan teknologi, karena IPA memiliki upaya untuk membangkitkan minat manusia serta kemampuan dalam mengembangkan ilmu pengetahuan dan teknologi serta pemahaman tentang alam semesta yang mempunyai banyak fakta yang belum terungkap dan masih bersifat rahasia sehingga hasil penemuannya dapat dikembangkan menjadi ilmu pengetahuan alam yang baru dan dapat diterapkan dalam kehidupan sehari-hari.

Fisika merupakan salah satu cabang ilmu pengetahuan alam atau sains. Sabagai cabang sains, fisika mempelajari segala sesuatu yang berhubungan dengan gejala-gejala alam
(Ruwanto,2013). Menurut Tjokrosujono (Nurhidayati, 2011) pelajaran fisika merupakan salah satu mata pelajaran sains yang didalamnya memuat konsep-konsep yang dapat mengembangkan kemampuan-kemampuan berpikir siswa dengan menggunakan berbagai fenomena alam dan penyelesaian masalah baik secara kualitatif maupun kuantitatif. Sehingga dapat dikatakan kemampuan memahami konsep dalam mempelajari fisika merupakan syarat mutlak bagi siswa untuk mencapai keberhasilan dan ketuntasan dalam belajar fisika.

Menurut Tomo (Nurhidayati, 2011) rendahnya hasil belajar IPA dapat disebabkan karena pemahaman yang salah tentang suatu konsep IPA (miskonsepsi) dan konsepsi awal yang telah dimilikinya, yang pada umumnya tidak sesuai dengan konsepsi ilmiah. Pelajaran IPA usaha yang dilakukan guru untuk 
memahami konsepsi awal siswa merupakan titil awal proses perubahan konsepsi siswa. Biasanya konsepsi awal yang kurang lengkap atau kurang sempurna dapat menimbulkan miskonsepsi pada siswa. Jadi, penguasaan konsep-konsep fisika serta keterkaitannya dapat membantu siswa untuk menguasai dan memahami konsep-konsep ilmu pengetahuan dan teknologi, sedangkan dengan metode ilmiah diharapkan siswa mempunyai minat, sikap, dan berpikir ilmiah untuk memecahkan masalah atau dalam menyelesaikan soal.

Menurut Suparno (2005), proses pembelajaran fisika haruslah mengembangkan perubahan konsep. Oleh karena itu, dalam mempelajari fisika diperlukan pemahaman konsep yang benar dan sesuai dengan konsep ilmuwan. Namun kenyataan dilapangan masih banyak terdapat siswa kurang atau tidak menguasai konsep-konsep fisika, atau bahkan mengalami kekeliruan dalam pemahaman konsep fisika tersebut, salah satunya adalah konsep pemuaian zat. Kekeliruan dalam pemahaman terhadap konsep suatu realita menimbulkan konsep-konsep lain yang tidak sesuai dengan konsep yang digunakan para ilmuwan disebut miskonsepsi (Sutrisno dkk, 2007). Miskonsepsi sering terjadi di dunia pendidikan, terutama dalam mata pelajaran fisika, sehingga menyebabkan kekeliruan atau kesalahan dalam menyelesaikan persoalan fisika.

Berdasarkan wawancara dengan guru bidang studi IPA di SMP Negeri 1 Tangaran Kabupaten Sambas, diperoleh informasi bahwa masih terdapat siswa mengalami kesulitan dalam memahami konsep-konsep. Salah satunya materi yang dianggap sulit adalah materi pemuian zat, dimana materi ini bersifat abstrak sehingga siswa sulit dalam mendeskripsikan konsep pemuaian zat, misalnya siswa masih keliru membandingkan antara pemuaian zat padat, pemuaian zat cair dan pemuaian gas. Selama ini guru IPA kelas VII SMP Negeri 1 Tangaran masih sering menyajikan materi secara konvensional dan jarang menggunakan media dalam pembelajaran, sehingga pada saat guru menjelaskan materi siswa hanya diam dan mendengarkan apa yang disampaikan guru.

Materi pemuaian zat merupakan salah satu materi fisika yang harus dipelajari di kelas VII. Materi ini setelah diberikan pada tingkat SMP, namun materi ini juga diberikan pada tingkat SMA dan di tingkat Perguruan Tinggi. Suparno (2005) mengatakan miskonsepsi disebabkan oleh beberapa faktor yaitu siswa, guru, buku teks, konteks, dan metode mengajar. Konsepsi siswa yang tidak sesuai dengan konsepsi ilmuwan ini dapat bertahan lama dan sulit diperbaiki selama dalam pendidikan formal. Setiap siswa yang mengalami miskonsepsi dapat disebabkan oleh konsep awal yang keliru dan kesalahan konsep yang diterima pada saat siswa belajar (Yulhendrik, 2011). Oleh karena itu, banyak guru fisika membantu siswa mengatasi kesalahan konsep dengan cara mengulangi penjelasan bahan beberapa kali. Akibatnya, siswa yang sudah mengerti menjadi bosan, dan siswa yang mengalami kesalahan menyelesaikan soal tetap tidak terbantu karena tidak tahu letak kesalahannya.

Mengungkapkan dan menemukan penyebab terjadinya kesalahan siswa telah diungkapkan oleh para peneliti yang sebelumnya. Suparno (2005) mengatakan ada tiga langkah untuk membantu siswa mengatasi miskonsepsi, salah satunya yaitumenerapkan perlakuan untuk mengatasi miskonsepsi tersebut. Perlakuan dalam penelitian ini yaitu kegiatan perbaikan (remediasi). Remediasi merupakan salah satu kegiatan yang dilaksanakan untuk memperbaiki kekeliruan yang dilakukan siswa sehingga mencapai kompetensi yang ditetapkan (Sutrisno dkk, 2007). Sejumlah kegiatan remediasi dirancang dengan seksama dan telah diuji coba sangat membantu meningkatkan hasil belajar, salah satunya dengan menggunakan booklet. Booklet adalah buku berukuran kecil (setengah kuarto) dan tipis, tidak lebih dari 30 halaman yang berisi tulisan dan gambar-gambar. Menurut Oxford Dictionary, menyatakan booklet is " a small thin book with a paper cover that contains information about a particular subject". Booklet yang dimaksud dalam penelitian ini adalah suatu bahan bacaan yang berbentuk buku kecil yang berisi penjelasan tentang kesalahan konsep yang dialami siswa dan penjelasan tentang konsep yang sesuai dengan konsep ilmuwan.

Kegiatan remediasi yang dimaksud yaitu penggunaan booklet diberikan kepada siswa yang mengalami kesalahan dalam soal pada tes 
awal, akan diberikan booklet. Booklet disusun sedimikian rupa disesuaikan dengan tes diagnostik dan manfaat penelitian dengan maksud memotivasi dan memudahkan siswa untuk memahami konsep pemuaian zat, sehingga diharapkan siswa lebih tertarik dan memudahkan dalam memahami konsep pemuaian zat serta siswa dapat mengetahui dimana letak kesalahan yang dialami dan memperbaikinya. Selain itu,booklet mudah dibawa sehingga dapat dipelajari baik dirumah maupun disekolah.

Alasan lain pemilihan remediasi menggunakan booklet ini yaitu dari beberapa hasil penelitian yang mendukung penggunaan booklet sebagai media pembelajaran efektif terhadap hasil belajar siswa, diantaranyahasil penelitian Nurhayati (2012) menunjukkan bahwa remediasi dengan penyediaan booklet dapat menurunkan jumlah kesulitan siswa dalam memahami konsep gerak parabola dan hasil penelitian Saputri (2009) menunjukkan bahwa remediasi dengan penyediaan booklet dapat menurunkan jumlah kesalahan siswa dalam memahami konsep gaya.

Berdasarkan latar belakang tersebut, peneliti merasa tertarik melakukan penelitian di SMP Negeri 1 Tangaran Kabupaten Sambas untuk mengetahui sejauh mana efektivitas remediasi menggunakan booklet dan disertai penjelasan jawaban yang benar dan mengapa yang lain salah dalam memperbaiki kesalahan siswa kelas VII SMP Negeri 1 Tangaran Kabupaten Sambas dalam menyelesaikan soalsoal pada materi pemuaian zat sehingga dapat meningkatkan hasil belajar siswa.

\section{METODE PENELITIAN}

Metode penelitian yang digunakan adalah eksperimen dengan rancangan One Group Pretest-Posttest Design. Adapun rancangan penelitian disajikan pada Tabel 1 .

Tabel 1. Rancangan Penelitian

\begin{tabular}{ccc}
\hline Tes Awal & Perlakuan & Tes Akhir \\
\hline $\mathbf{T}_{\mathbf{1}}$ & $\mathrm{X}$ & $\mathrm{T}_{2}$ \\
\hline
\end{tabular}

Sampel penelitian ini berjumlah 27 siswa. Teknik pengambilan sampel yang digunakan adalah teknik intact group (kelompok utuh), yaitu pengampilan sampel secara utuh dari populasi yang bersifat homogen dengan menetapkan satu atau beberapa kelas sebagai kelompok yang akan diteliti (Sutrisno dalam Yulhendrik, 2011). Pengambilan sampel dilihat berdasarkan nilai rata-rata ulangan harian siswa, kelas rata-rata nilainya rendahmenjadi sampel dalam penelitian ini.Alat pengumpul data dalam penelitian ini yaitu tes tertulis berupa pilihan ganda menggunakan tiga alternatif jawaban dan disertai dengan alasan terbuka.

Efektivitas penggunaan modul untuk meremediasi penurunan kesalahan siswa dapat dilihat berdasarkan proporsi penurunan jumlah kesalahana tiap siswa dan tiap indikator materi pemuaian zat padat. Penurunan kesalahan tiap siswa dapat diketahui proporsinya menggunakan Persamaan 1.

$$
\Delta n=\frac{n_{0}-n_{t}}{n_{0}}
$$

Berdasarkan Persamaan 1 dapat diketahui bahwa $\Delta n$ adalah proporsi penurunan jumlah kesalahan tiap siswa, $n_{0}$ adalah jumlah kesalahan siswa pada tes awal dan $n_{t}$ adalah jumlah kesalahan siswa pada tes akhir.

Penurunan kesahan tiap indikator dapat diketahui proporsinya berdasarkan Persamaan 2.

$$
\Delta s=\frac{s_{0}-s_{t}}{s_{0}}
$$

Berdasarkan Persamaan 2 dapat diketahui bahwa $\Delta s$ adalah proporsi penurunan kesalahan tiap indikator, $s_{0}$ adalah jumlah siswa yang mengalami kesalahan pada tes awal pada tiap indikator dan $s_{t}$ adalah jumlah siswa yang mengalami kesalahan pada tes akhir pada tiap indikator.

Efektivitas penggunaan modul untuk meremediasi penurunan kesalahan siswa dikategorikan berdasarkan barometer efektivitas menurut Hattie (2009). Adapun kategori tersebut disajikan pada Tabel 2. 
JEMS (Jurnal Edukasi Matematika dan Sains)

Tersedia online di: http://e-journal.ikippgrimadiun.ac.id/index.php/JEMS

Volume 4, Nomor 2, September 2016, hal 96-101

Tabel 2. Kategori Efektivitas

\begin{tabular}{cc}
\hline$\Delta n / \Delta s$ & Tingkat Efektivitas \\
\hline$-0,20-0,00$ & negatif \\
\hline $0,01-0,40$ & rendah \\
\hline $0,41-0,70$ & sedang \\
\hline $0,71-1,20$ & tinggi
\end{tabular}

\section{HASIL DAN PEMBAHASAN}

Analisis data pada penelitian ini difokuskan padapenurunan jumlah kesalahan untuk tiap siswa dan tiap indikator antara tes awal dan tes akhir. Data dari hasil penelitian ini yaitu berupa penurunan jumlah kesalahan dan tingkat efektivitas penggunaan booklet tiap siswa dan tiap indikator. Distribusi proporsi penurunan kesalahan tiap siswa dan tingkat efektivitasnya dapat dilihat pada Tabel 4. Berdasarkan data pada Tabel 4, dapat disimpulkan bahwa penggunaan booklet efektif meremediasi kesalahan siswa dengan kategori tinggi bagi 20 siswa, efektivitas sedang bagi 6 siswa dan efektivitas rendah bagi 1 siswa.

Distribusi proporsi penurunan kesalahan tiap indikator dan tingkat efektivitasnya dapat dilihat pada Tabel 5. Berdasarkan Tabel 5 terdapat lima indikator yang proporsi penurunan kesalahan dalam rentang 0,71-1,20 hal ini menandakan bahwa booklet efektif untuk meremediasi kesalahan dalam materi pemuaian zat padat dengan kategori tinggi. Selain itu terdapat empat indikator yang proporsi penurunan kesalahan dalam rentang 0,41-0,70 hal ini menandakan bahwa booklet efektif untuk meremediasi kesalahan dalam materi wujud zat padat dengan kategori sedang. Lebih jauh lagi berdasarkan Tabel 5 hanya ada satu indikator yang proporsi penurunan kesalahan dalam rentang 0,00-0,40 hal ini menandakan bahwa booklet efektif meremediasi kesalahan dalam materi wujud zat padat dengan kategori rendah.

Tabel4. Proporsi Penurunan Kesalahan dan Tingkat Efektivitas Penggunaan Booklet Tiap Siswa

\begin{tabular}{ccc}
\hline $\mathrm{n}$ & Jumlah Siswa & $\begin{array}{c}\text { Tingkat } \\
\text { Efektivitas }\end{array}$ \\
\hline $0,71-1,20$ & 20 & Tinggi \\
\hline $0,41-0,70$ & 6 & Sedang \\
\hline $0,00-0,40$ & 1 & Rendah \\
\hline
\end{tabular}

Dari hasil data yang diperoleh, penggunaan booklet dikatakan efektif untuk meremediasi kesalahan dalam materi wujud zat. Hal ini dapat dilihat pada Tabel 4 dan 5 dimana terdapat penurunan kesalahan baik berdasarkan tiap siswa maupun tiap indikator dengan kategori tinggi, sedang dan rendah.Berdasarkan hal tersebut,penggunaan booklet untukmeremediasi dapat memperbaiki kesalahan konsep siswa. Berdasarkan kriteria ketepatan dan objektivitas, remediasi ini tepat diberikan pada siswa yang mengalami kesalahan. Hal ini ditunjukkan oleh adanya penurunan jumlah kesalahan siswa dan penurunan jumlah kesalahan siswa yang mengalami kesalahan dalam menyelesaikan soal-soal tentang pemuaian zat. Hal ini sejalan dengan (Daud, 2004) bahwa pengunaan booklet efektif digunakan untuk meremediasi kesalahan siswa pada konsep tertentu.

Temuan ini juga serupa dengan temuan hasil penelitian Nurhayati (2012) terhadap siswa kelas XI SMA Negeri 7 Pontiaanak, efektivitas penyediaan booklet tergolong tinggi bagi 29 siswa dan tergolong sedang bagi 8 siswa sedangkan dalam penelitian yang dilakukan Saputri (2009) yang dilakukan siswa kelas X SMA Negeri 4 Pontianak, remediasi dengan pemberian umpan balik berupa booklet memiliki efektivitas tinggi. Dari total 34 siswa, efektivitas tergolong tinggi bagi 26 siswa, tergolong sedang bagi 6 siswa dan tergolong rendah bagi 2 siswa. 
JEMS (Jurnal Edukasi Matematika dan Sains)

Tersedia online di: http://e-journal.ikippgrimadiun.ac.id/index.php/JEMS

Volume 4, Nomor 2, September 2016, hal 96-101

Tabel 5. Proporsi Penurunan Kesalahan dan Tingkat Efektivitas Penggunaan Booklet Tiap Indikator

\begin{tabular}{|c|c|c|}
\hline$\Delta \mathrm{S}$ & Indikator & Tingkat Efektivitas \\
\hline $0,71-1,20$ & $\begin{array}{l}\text { 1. Mengidentifikasi peristiwa pemuaian pada air yang } \\
\text { dipanaskan dalam wadah. } \\
\text { 2. Menjelaskan konsep pemuaian dalam kehidupan sehari- } \\
\text { hari pada pemasangan kawat listrik. } \\
\text { 3. Menjelaskan konsep pemuaian dalam kehidupan sehari- } \\
\text { hari pada pemasangan kaca jendela. } \\
\text { 4. Menjelaskan konsep pemuaian pada cincin yang } \\
\text { dipanaskan. } \\
\text { 5. Menjelaskan pemuaian zat cair pada wadah yang diisi } \\
\text { air. }\end{array}$ & Tinggi \\
\hline $0,41-0,70$ & $\begin{array}{l}\text { 1. Menjelaskan konsep pemuain pada zat padat. } \\
\text { 2. Menyebutkan contoh zat yang dapat mengalami } \\
\text { pemuaian panjang. } \\
\text { 3. Menyebutkan contoh zat yang dapat mengalami } \\
\text { pemuaian luas. } \\
\text { 4. Menyebutkan contoh zat yang dapat mengalami } \\
\text { pemuaian volume. }\end{array}$ & Sedang \\
\hline $0,00-0,40$ & $\begin{array}{l}\text { 1. Menjelaskan konsep pemuaian gas pada botol yang } \\
\text { dipanaskan. }\end{array}$ & Rendah \\
\hline
\end{tabular}

Sutrisno (2001) menyatakan bahwa remediasi menggunakan booklet memiliki kelebihan dan kekurangan. Kelebihan remediasi menggunakan booklet antara lain adalah memiliki efect size tinggi, siswa dapat mengetahui letak kesalahan yang dialaminya, siswa akan menggunakan pikiran dan pengetahuannya secara aktif dan efektif dalam memahami materi, booklet mudah dibaca dan dibawa sehingga siswa dapat belajar tanpa menunggu penjelasan dari guru, memudahkan guru terutama untuk kelas besar dan menghemat waktu dalam proses belajar mengajar.

Temuan penelitian ini juga menunjukkan bahwa efektivitas penggunaan booklet untuk meremediasi kesalahan dalam materi pemuaian zat tidak hanya berkategori tinggi, namun juga ditemukan efektivitas yang sedang dan rendah. Hal tersebut menjadi kekurangan dari remediasi menggunakan booklet karena tidak semua siswa dapat memahami suatu konsep fisika hanya dengan membaca saja. Selain itu, diperlukan penelitian lanjutan dengan fokus desain booklet yang baik (redable dan comprehensible) pada materi fisika lainnya.

\section{KESIMPULAN}

Hasil penelitian menunjukkan bahwa penggunaan boklet efektif untuk meremediasi kesalahan siswa pada materi pemuaian zat dengan kategori tinggi untuk 20 siswa, sedang untuk 6 siswa dan rendah untuk 1 siswa. Selain itu penggunaan booklet juga efektif untuk meremediasi kesalahan pada materi pemuaian zat dengan kategori tinggi untuk 5 indikator, sedang untuk 4 indikator dan rendah untuk 1 indikator.Setelah penelitian selesai dilakukan, terdapat beberapa hal yang bisa menjadi saran bagi penelitian selanjutnya: (1) Remediasi dengan penggunaan booklet dapat menurunkan jumlah kesalahan siswa tentang konsep pemuaian zat, maka Diharapkan hasil penelitian ini dapat memberikan alternatif bagi guru dalam melakukan kegiatan remediasi untuk membantu kesalahan siswa dalam memahami konsep-konsep fisika; (2) Remediasi menggunakan bahan bacaan berbentuk booklet dalam penelitian ini masih memiliki berbagai kelemahan yaitu masih ada siswa yang kurang memahami isi booklet. Oleh karena itu dalam penelitian lebih lanjut, disarankan agar peneliti memperhatikan alokasi 
waktu untuk penyusunan, waktu untuk memberikan bimbingan, penyusunan booklet lebih terstruktur serta disusun dengan bahasa yang mudah dipahami siswa. Sehingga diharapkan bahan bacaan berstruktur booklet dapat diterima secara komprehensif sekaligus digunakan sebagai bahan remediasi dalam pendidikan; (3) Untuk penelitian lebih lanjut, sebaiknya pemilihan kata-kata di dalam soal yang sesuai dengan karakteristik siswa sehingga siswa dapat memahami soal; (4) Disarankan untuk penelitian selanjutnya agar memperhatikan tingkat keterbacaan booklet yang dibuat.

\section{DAFTAR PUSTAKA}

Daud, Jaleluddin. (2004). Prosedur Perencanaan. Medan : Fakultas Teknik USU. (Online). (library.usu.ac.id/download/ft/sipiljeluddin2.pdf), diakses 14 Juni 2014.

Hattie, John. (2009). Research Barometer Effectiveness.

(Online). (growthmindseteaz.org/johnhattie.html), diakses 10 juni 2014.

Nurhayati. (2012). Penyediaan Booklet untuk Meremediasi Kesulitan Siswa dalam Memahami Konsep Gerak Parabola di Kelas XI SMA Negeri 7 Pontianak. Jurnal Edukasi, Vol. 8, No.2, pp.192200.

Nurhidayati. (2011). Remediasi Menggunakan Booklet untuk Memperbaiki Miskonsepsi Siswa pada Materi Gerak Lurus Beraturan di Kelas VII SMP Negeri 3 Sukadana. Skripsi. Pontianak: FKIP UNTAN. (Tidak Dipublikasikan)

Ruwanto, B. (2013). Asyik Belajar Fisika. Jakarta: Gramedia.

Saputri, F.D. (2009). Penyediaan Booklet Untuk Meremediasi Kesalahan Siswa dalam Memahami Konsep Gaya di Kelas X SMA Negeri 4 Pontianak.Skripsi. Pontianak: FKIP UNTAN.
Suparno, P. (2005). Miskonsepsi dan Perubahan Konsep dalam Pendidikan Fisika. Jakarta: Grasindo.

Sutrisno, Leo. (2001). Konfirmasi Data. (Online).

(http://www.scribd.com/documentdow nloads/4596008?secretpassword=\&ext ension=ppt), diakses 4 april 2014.

Sutrisno, Leo, Kresnadi, Hery, dan Kartono. (2007). Pengembangan Pembelajaran IPA SD. Jakarta: LPJJ PGSD.

Yulhendrik. (2011). Deskripsi Miskonsepsi Siswa Tentang Pemuaian Zat di Kelas VII SMP Negeri 2 Sungai Raya Pontianak. Skripsi. Pontianak: FKIP UNTAN. (Tidak Dipublikasikan). 